\title{
Modelling the hydrocarbon generation and migration in the West Netherlands Basin, the Netherlands
}

\author{
R.T. van Balen ${ }^{1,2}$, F. van Bergen ${ }^{1}$, C. de Leeuw ${ }^{1}$, H. Pagnier ${ }^{1}$, \\ H. Simmelink ${ }^{1}$, J.D. van Wees ${ }^{1} \&$ J.M. Verweij ${ }^{1}$ \\ ${ }^{1}$ Netherlands Institute of Applied Geoscience TNO - National Geological Survey, Department of \\ Geo-Energy, P.O. Box 80015, 3508 TA Utrecht. \\ ${ }^{2}$ corresponding author; e-mail: r.vanbalen@nitg.tno.nl; http://www.nitg.tno.nl/basin-modelling
}

Manuscript received: 15 November 1999; accepted in revised form: 21 December 1999

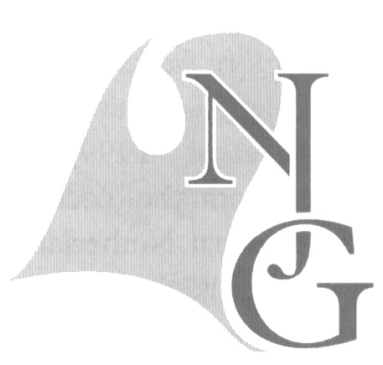

\begin{abstract}
The hydrocarbon systems of the Mesozoic, inverted West Netherlands Basin have been analyzed using 2-D forward modelling. Three source rocks are considered in the modelling: Lower Jurassic oil-prone shales, Westphalian gas-prone coal deposits, and Lower Namurian oil-prone shales. The Lower Namurian hydrocarbon system of the basin is discussed for the first time.

According to the modelling results of the Early Jurassic oil system, the oil accumulations were filled just after the main inversion event. Their predicted locations are in agreement with exploration results. Modelling results of the Westphalian gas system, however, show smaller and larger sized accumulations at unexplored locations. The gas reservoirs were filled during the Late Jurassic-Early Cretaceous rifting phase. Results of modelling of the Lower Namurian oil system indicate that gas formed by secondary cracking of the oils can have mixed with the Westphalian coal-derived gas. Such a mixing is inferred from geochemical analyses. The existence of a Lower Namurian hydrocarbon system in the West Netherlands Basin implies that hydrocarbons are possibly trapped in the Westphalian and Namurian successions. These potential traps in the basin have not yet been explored.
\end{abstract}

Keywords: hydrocarbon generation and migration modelling, North Sea Basin, Rijswijk oil province, subsidence modelling, West Netherlands Basin

\section{Introduction}

The hydrocarbon generation and migration in the West Netherlands Basin (WNB) have been studied quantitatively. In addition to the relatively well-known play concepts based on Lower Jurassic and Westphalian source rocks (Bodenhausen \& Ott, 1981; De Jager et al., 1996), a play based on Lower Namurian marine source rocks has been analyzed.

The purpose of the study was to increase the understanding of the evolution of hydrocarbon accumulations in terms of timing of hydrocarbon generation and migration, in relation to the tectonic evolution of the basin The results of the study may help to identify new hydrocarbon accumulations. The study has been carried out in the framework of the mapping of the subsurface of the Netherlands, Map Sheets VII and VIII (in progress).
The WNB is located in the southwestern part of the Netherlands and the adjacent offshore area (Fig. 1). The basin is bounded to the south by the LondonBrabant Massif; the Zandvoort Ridge/IJmuiden High to the north separates it from the Central Netherlands Basin and the Broad Fourteens Basin (Van Adrichem Boogaert \& Kouwe, 1993-1997). Towards the southeast, the basin merges with the Roer Valley Graben. The WNB is part of a system of Late Jurassic/Early Cretaceous transtensional basins that further includes, among others, the Central Netherlands Basin, the Broad Fourteens Basin and the Roer Valley Graben in the Netherlands, the Sole Pit Basin in the UK sector of the North Sea, and the Lower Saxony Basin in Germany (Fig. 1; Betz et al., 1987; Van Wijhe, 1987; Ziegler, 1990). These basins were inverted in several events during the Late Cretaceous to Oligocene (Heybroek, 1974; Van Wijhe, 1987; Gras \& Geluk, 1999). 


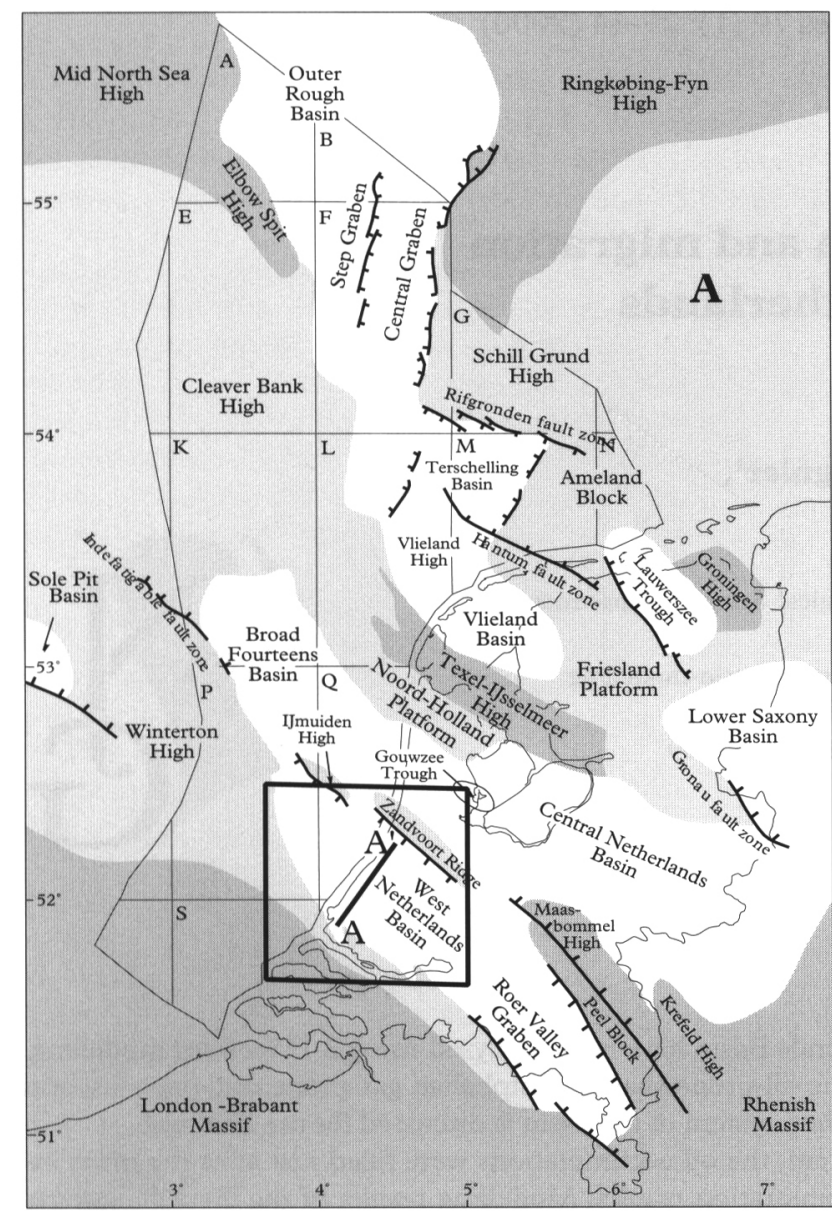

The first part of the present contribution provides a review of the evolution of the WNB. Next, the hydrocarbon systems are forward modelled, using the cross-section shown in Figure 2. The cross-section traverses two important hydrocarbon accumulations, i.e., the De Lier and Wassenaar fields (Fig. 1-B). The predicted hydrocarbon generation history of the three source rocks and the timing of the migration and trapping of the derived hydrocarbons are presented in the following part of the present contribution.

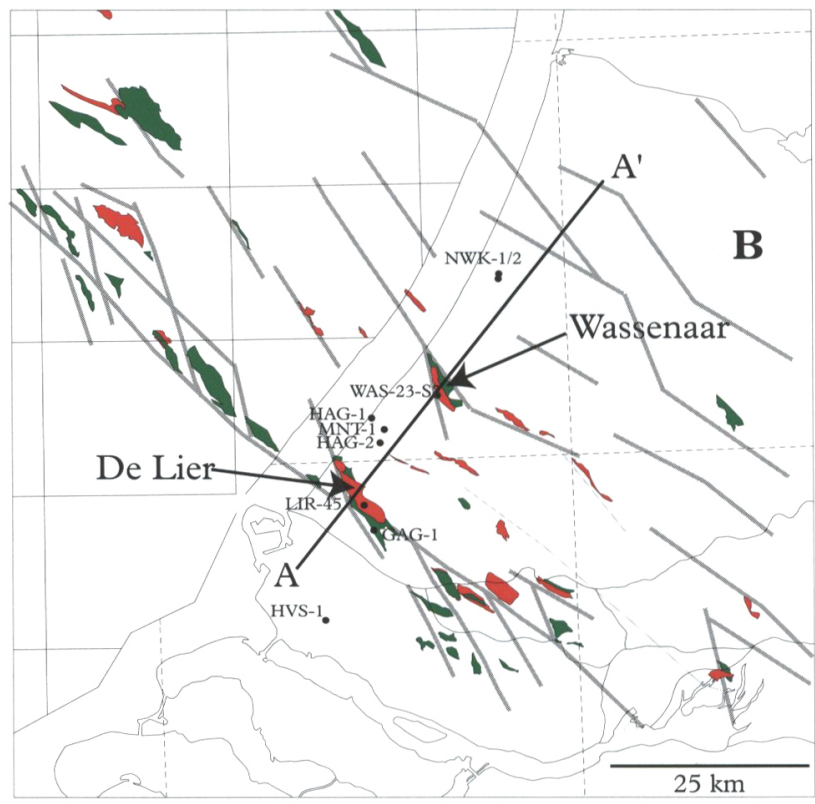

Fig. 1. Location map.

A: location of the West Netherlands Basin (modified after Van Adrichem Boogaert \& Kouwe, 1993-1997). The box indicates the postion of the map shown in Figure 1B. The line A-A' denotes the position of the cross-section depicted in Figure 2.

B: detailed view of the West Netherlands Basin, including the location of hydrocarbon fields; see Figure $1 \mathrm{~A}$ for location. Oil fields are colored red, the green colors represent gas fields. The indicated fault pattern is based on preliminary mapping results. The line AA' denotes the modelled cross-section.

\section{Basin evolution}

The WNB (see Fig. 3 for its stratigraphic column) underwent a polyphase tectonic deformation from the Late Carboniferous onwards. Although the basin has commonly been described as one structural entity, it is actually fragmented into a number of smaller elements, bounded by long, NW-trending faults (Fig. 1). Its Late Carboniferous-Tertiary history can be subdivided into four stages. The evolution of the basin is

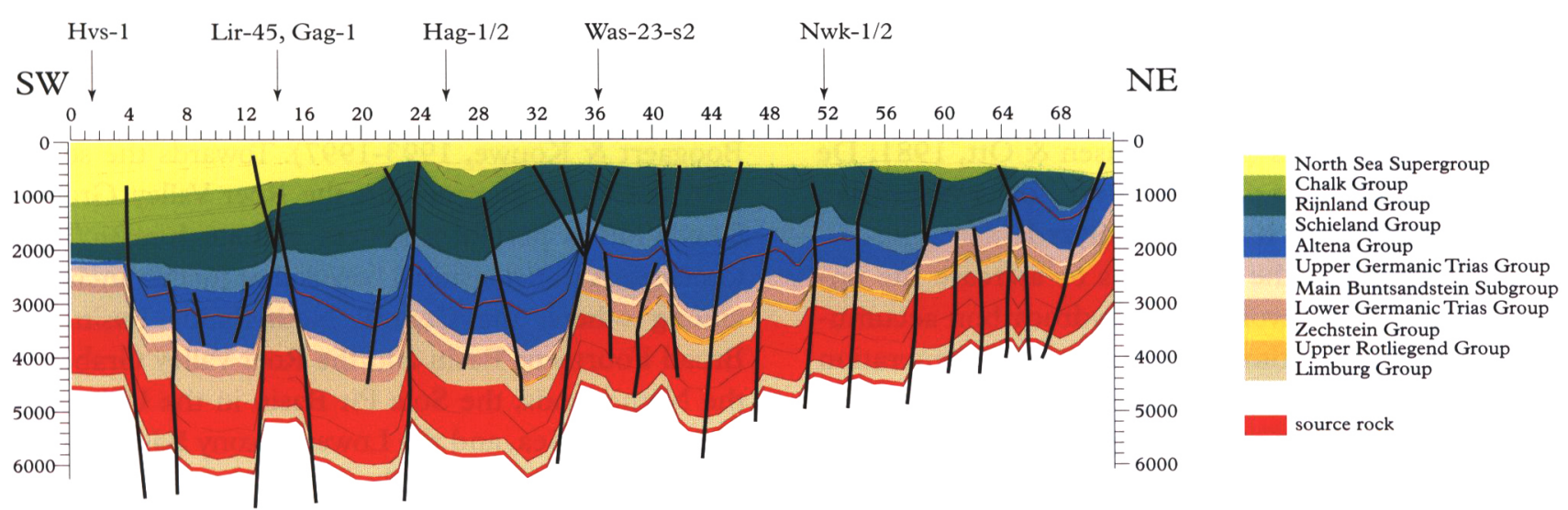

Fig. 2. The modelled cross-section (see Figs. 1A and 1B for location). The location of the two most important hydrocarbon fields along the section, i.e. the De Lier and Wassenaar fields, and the position of various wells mentioned in the text have been indicated. Horizontal scale in $\mathrm{km}$, vertical scale in $\mathrm{m}$. 


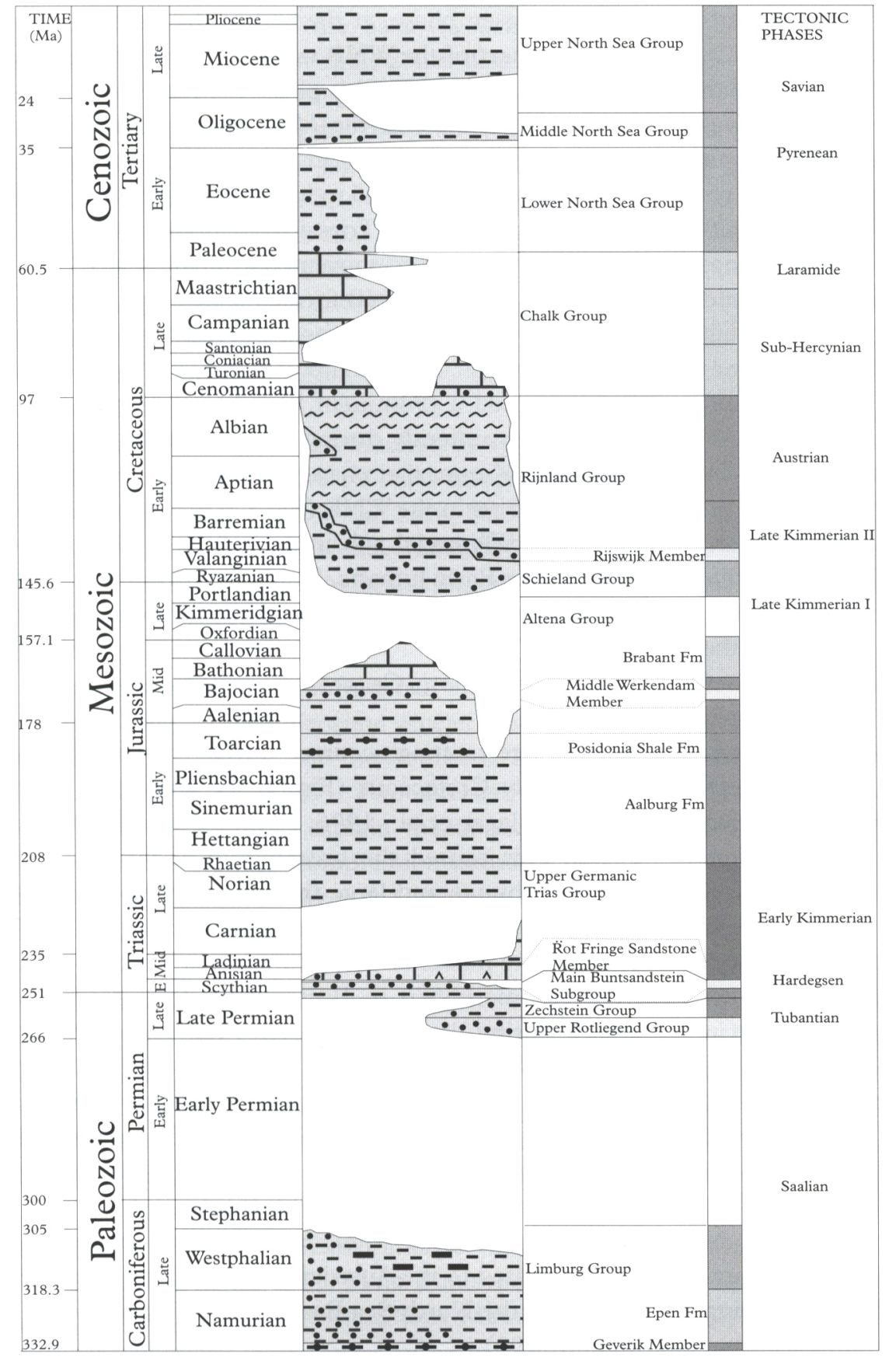

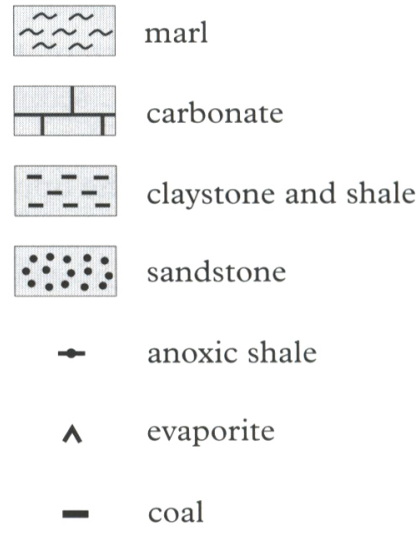

Fig. 3. Stratigraphy of the West Netherlands Basin. Numerical ages in the Namurian and Jurassic to Tertiary are after Harland et al. (1990), in the Triassic and Permian after Menning (1995), and in the Westphalian and Stephanian after Lippolt et al. (1984). The grey column represents the subdivision in modelling units. The grey-scale stands for the hydrogeologic characteristics of the interval at deposition (light $=$ high permeability, dark $=$ low permeability). described below briefly for each stage.

For the Late Permian and onwards, the evolution of the WNB is illustrated by tectonic-subsidence curves for two representative wells located along the cross-section, i.e. De Lier-45 (Lir-45) and Wassenaar-23-S2 (Was-23-S2), shown in Figure 4. The tectonic-subsidence curves have been made using backstripping analysis (Steckler \& Watts, 1978). In the present analysis, subsidence is corrected for compaction using lithology-dependent porosity/depth relationships (e.g., Sclater \& Christie, 1980); isostasy corrections are based on a local isostatic approximation. The adopted ages of the sedimentary units are based on the ages given by the Dutch nomenclature
(Fig. 3; Van Adrichem-Boogaert \& Kouwe, 19931997).

\section{Late Carboniferous-Early Permian stage}

The Mesozoic WNB developed upon the Campine Basin, which is of Variscan origin. The axis of this Variscan basin underlies the southwestern part of the WNB. The basin is situated north of the London-Brabant Massif and displayed strong subsidence from the Namurian onwards (Langenaeker, 1998). During the Variscan orogeny, from the Westphalian D to the Early Permian, uplift and erosion took place; especially the Zandvoort Ridge was strongly uplifted. Erosion 
during the uplift removed about $500 \mathrm{~m}$ of sediments in the northern part of the cross-section (Fig. 2), where Westphalian $\mathrm{C}$ sediments underly the Permian succession. The southern part of cross-section was uplifted much less; the uppermost Carboniferous unit is formed by Westphalian D sediments and erosion removed about $250 \mathrm{~m}$ of sediments. The Late Carboniferous basin was filled with a predominantly finegrained succession, comprising a basal hot-shale and coal-bearing strata in the middle part (Van Adrichem Boogaert \& Kouwe, 1993-1997). The youngest succession comprises red-beds.

\section{Late Permian - Middle furassic 'prerift'stage}

Sedimentation resumed during the Late Permian, with deposition of the sandstones of the Upper Rotliegend Group. The WNB formed a rather stable block at the time, situated at the southern margin of the main basin. The sedimentary succession comprises mainly fluvial and aeolian sandstones of the Upper Rotliegend Group, followed by claystones, siltstones and carbonates of the Zechstein Group. These sediments thicken towards the Zandvoort Ridge/IJmuiden High; the ridge itself, however, appears to have been a structurally high area during the Upper Rotliegend, in view of the thin succession encountered in wells (Geluk et al., 1996). During the second Late Permian rift pulse, the WNB was uplifted, and uppermost Zechstein rocks overly the Upper Rotliegend Group in the central part of the basin (Geluk, 1999a).

The Early Triassic was characterised by regional, thermal subsidence (Fig. 4). The WNB formed part of a gentle, northwards dipping basin. Fine-grained lacustrine sediments were laid down initially, followed by a sandy fluvial and aeolian succession (Main Buntsandstein Subgroup). These sediments were partly derived from the London-Brabant Massif. During

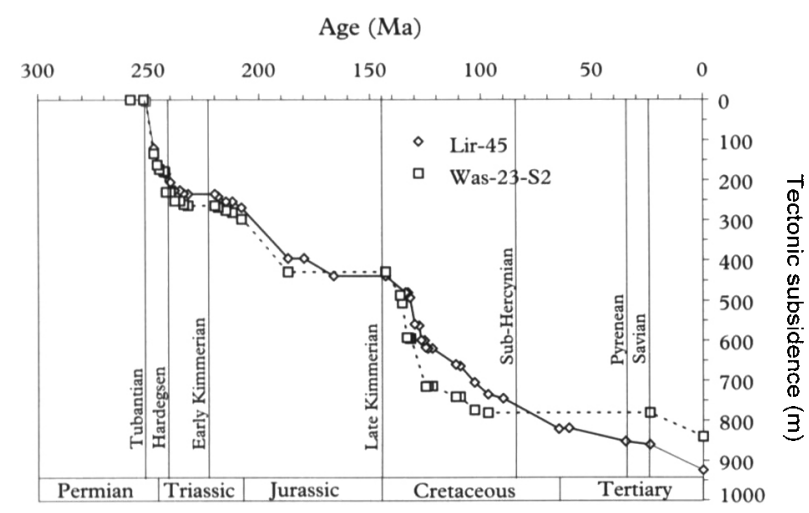

Fig. 4. Tectonic-subsidence curves for two wells: De Lier-45 (Lir45) and Wassenaar-23-S2 (Was-23-\$2), obtained by backstripping analyses. The results are based on the present-day sedimentary succession in the wells. See Figure 1B for location of the wells. the Hardegsen phase, at the end of the Scythian, the northern part of the WNB was uplifted (Geluk et al., 1996). Erosion during this phase has resulted in a decrease in thickness of the Main Buntsandstein Subgroup from about $180 \mathrm{~m}$ in the southern part of the cross-section to about $45 \mathrm{~m}$ in the northern part.

The Middle to Late Triassic development was characterised by tectonic movements of the Early Kimmerian phase. The WNB formed a structurally rather simple large-scale half-graben, bounded to the north by a major fault zone (Geluk, 1999b). The Zandvoort Ridge formed a prominent high block. Faulting occurred intermittently during the Anisian to Carnian. The Early Kimmerian phase resulted in a large intraTriassic hiatus in the WNB (Fig. 4). From the Norian onwards, differential subsidence of the WNB is evident. In the Early Jurassic, faulting caused differential subsidence of the various subunits of the basin.

\section{Late furassic - Early Cretaceous 'synrift'stage}

The strongest rifting occurred during the Late Jurassic to Early Cretaceous (Fig. 4; see also Van Wijhe, 1987; De Jager et al., 1996; Racero-Baena \& Drake, 1996). This caused the breaking-up of the basin in various subunits and large thickness variations in the Late Jurassic basin infill. The rifting occurred in several discrete pulses of short duration in the time-span from Kimmeridgian to Barremian; rifting gradually ceased during the Aptian-Albian (Van Wijhe, 1987), but subsidence of the WNB continued into the Late Cretaceous. The tectonic-subsidence curves (Fig. 4) show that the subsidence evolution can be subdivided into two, more or less linear, subphases. At the transition between these two subphases, in the Early Aptian, the extensional strain rate suddenly decreased. This is related to the Austrian compressive phases occurring in the North Sea Basin (a.o. Oakman \& Partington, 1998).

The Late Jurassic-Early Cretaceous rifting was accompanied by repeated igneous activity, particularly in the southeastern part of the basin. The volcanism is indicative of deep crustal fracturing (Van Wijhe, 1987), which may have had a local impact on maturity. In the WNB, radiometrically determined ages of volcanic rocks are $133 \pm 2 \mathrm{Ma}$ and $150 \mathrm{Ma}$.

\section{Late Cretaceous - Quaternary 'postrift' and inversion stages}

During the Santonian-Campanian interval, compressive forces caused the inversion of the WNB (Van Wijhe, 1987), followed by the development of contemporaneous marginal troughs sensu Voigt (1963) to 
the north and south of the basin (Voorne Trough, Zandvoort Ridge). Major fault zones display reverse movements, and many of the oil-bearing structures have been formed during this phase (see, a.o., Bodenhausen \& Ott, 1981; De Jager et al., 1996; RaceroBaena \& Drake, 1996). The overall style of the inversion movements suggests that they developed in response to transpression (Van Wijhe, 1987; Dronkers \& Mrozek, 1991). The inversion resulted in pronounced uplift of the former depocentres, and in subsequent deep erosion. Sedimentation was limited to the marginal troughs.

During the Maastrichtian-Danian, inversion movements ceased, and the whole WNB was covered again by sediments. At the end of the Early Paleocene, and during the Eocene-Oligocene, renewed uplift occurred of the WNB, resulting in the removal of almost all Paleogene sediments (Fig. 2; Bodenhausen \& Ott, 1981).

During the Neogene, subsidence of the WNB accelerated (Fig. 4). The Neogene acceleration of subsidence is characteristic of the southern North Sea Basin (Kooi et al., 1989). Two alternative models have been proposed to explain the observed subsidence: extension and compression-induced flexure (Kooi et al., 1989; Van Wees \& Cloetingh, 1996; Van Balen et al., 1998; Van Balen \& Podladchikov, 1998).

\section{The hydrocarbon system}

In the WNB, also known as the Rijswijk oil province, oil was discovered in 1938 in Paleocene sediments (Bodenhausen \& Ott, 1981). After geophysical surveys had been conducted, the Rijswijk field was discovered in 1953. Many fields have been discovered since then (Fig. 1). The two major exploration objectives in the WNB are sandstones of the Main Buntsandstein Subgroup and the Röt Fringe Sandstone Member, which contain mainly gas (GIP $65 \cdot 10^{9} \mathrm{~m}^{3}$ ) and minor quantities of oil (De Jager et al., 1996; Racero-Baena \& Drake, 1996), and the Lower Cretaceous sandstones containing mainly oil (STOIIP $68 \cdot 10^{6}$; Bodenhausen \& Ott, 1981; De Jager et al., 1996; Racero-Baena \& Drake, 1996). Secondary reservoir objectives are situated in the Permian Zechstein Fringe Sandstone Members, in the Middle Jurassic Middle Werkendam Member and Brabant Formation, in the Upper Cretaceous Chalk Group, and in the Lower Tertiary Dongen Sand Member (De Jager et al., 1996; Geluk et al., 1996).

The hydrocarbon accumulations in Triassic reservoirs occur in tilted fault block structures (Fig. 5). The traps depend on top sealing by Upper Triassic evaporites, tight sandstones, siltstone, shales and dolostones (Fig. 3; see also Geluk et al., 1996; Spain \&

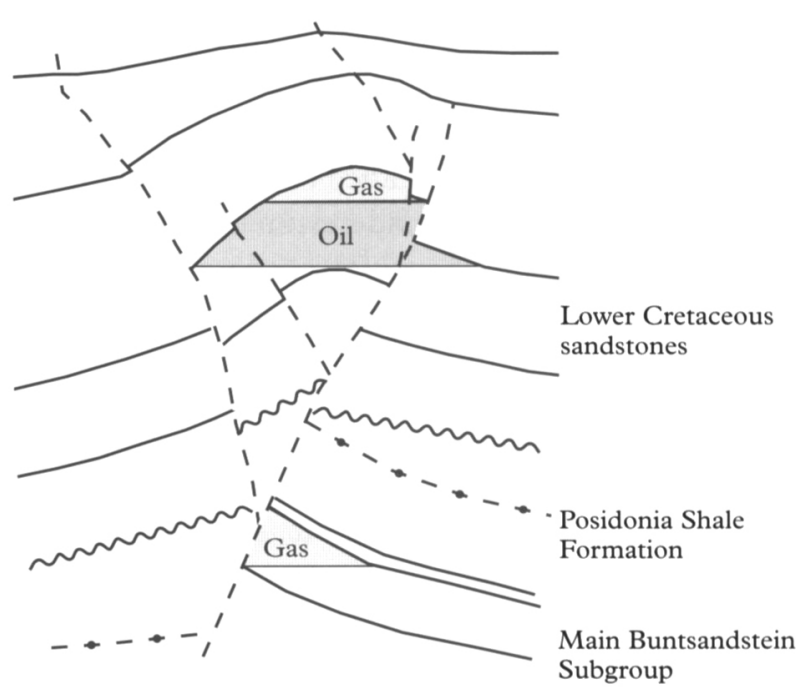

Fig. 5. Characteristic trap situation in the WNB: gas occurs in a tilted fault-block structure. The oil is situated in the overlying anticline (simplified after De Jager et al., 1996).

Conrad, 1997), and lateral sealing by faulting-induced juxtaposition of the reservoir against Lower and Middle Jurassic shales (De Jager et al., 1996). Based on $\mathrm{K} / \mathrm{Ar}$ dating of diagenetically formed illite, the age of gas emplacement for a well in the Broad Fourteens Basin is inferred to be $140 \mathrm{Ma}$ (Lee et al., 1985). As the WNB has a similar tectonic history as the Broad Fourteens Basin (Van Wijhe et al., 1987), the timing of gas emplacement can also have been similar.

The hydrocarbons in reservoirs of the Lower Cretaceous are trapped in anticlinal structures formed during the inversion events, above reversed normal faults (Fig. 5). They are mainly filled by oil, but substantial quantities of gas also occur. The oils are biodegraded along the northern and eastern rims of the WNB, where Lower Cretaceous and Jurassic formations were exposed to the surface during the inversion phases (De Jager et al., 1996). This implies that these reservoirs were filled before or during the inversion events.

\section{Source rocks}

Two major source rocks in the WNB are generally accepted (De Jager et al., 1996). The first is in a thick succession of Westphalian sediments, which contains humic source rocks (Type III) in coals and shales. The average coal content of the Westphalian A and B succession is about 5.5\% (Dusar et al., 1998). The TOC of the coals is at least $70 \%$ (Van Bergen, 1998). The second important source rock is in the Lower Jurassic: Type II source rocks occur in the Posidonia Shale Formation (5-10\% TOC) and the underlying Aalburg Formation (1-3\% TOC; De Jager et al., 1996; Van Bergen, 1998). The source rocks situated in 
the Upper Jurassic (Bodenhausen \& Ott, 1981; Roelofsen \& De Boer, 1991) and in the Namurian and Dinantian deposits (Winstanley, 1993; Cameron \& Ziegler, 1997) are generally considered to be of minor importance. The importance of Namurian source rocks could however, be underestimated, as will be detailed below.

According to De Jager et al. (1996), most of the oils and gases in Upper Jurassic and Lower Cretaceous reservoirs can be correlated with extracts from the Lower Jurassic Posidonia Shale Formation (Fig. 3); minor amounts are a mixture of hydrocarbons derived from Lower Jurassic and Westphalian source rocks. Based on alkane and sterane distributions, however, Van Bergen (1998) concluded that all the oils are chemically similar to those in the Lower Jurassic source rocks.

The gases in Triassic reservoirs have either a pure Westphalian or a mixed origin (De Jager et al., 1996). Based on the carbon-isotope ratios, carbon molecular gas ratios and nitrogen isotope ratios, Gerling et al. (1999) also concluded that Carboniferous and Upper Permian gas fields in the western part of the Southern North Sea Basin are of a mixed origin, with a lowmaturity terrestrial source and a more mature marine source. The second source could be a Namurian marine source rock. In the well Geverik-1 situated to the south of the southeastern part of the Roer Valley Graben, a Type II source rock has been postulated for the basal, marine Namurian hot shales (Geverik Member), based on bitumen presence. The source rock has a total thickness of $15-25 \mathrm{~m}$ and a TOC of about $8 \%$. The hot shales have been interpreted as having settled from suspension in an anoxic basin with restricted circulation (Van Adrichem Boogaert \& Kouwe, 1993-1997), similar to the Posidonia Shale Formation. The overlying Epen Shale formation is the equivalent of the Edale Shale and similar basal Namurian shales in the southern North Sea Basin. These series have source rocks that are characterized by TOC's ranging from 2-5\% (Cornford, 1998). Based on plant remains in the well Geverik-1, the source rocks of the Epen Formation are of Type III. In general, the kerogen type of the Namurian shales depends on the paleogeographic depositional setting (Gerling et al., 1999): the Type III source was deposited in a deltaic facies, whereas the Types I and II were deposited in an open-marine/starved facies.

\section{Maturity}

The vitrinite reflectance $(\% \mathrm{Rr})$ of Westphalian coals and Lower Jurrasic shales from several wells in the WNB has been reported by Van Bergen (1998). From south to north along the cross-section, the top of the Westphalian increases in maturity. At the southern end of the section, the top of the coals is within the oil window; at the northern end, the same interval is situated beyond or at the end of the gas window.

The number of $\% \mathrm{Rr}$ measurements on Lower Jurassic source rocks is limited. Moreover, these marine source rocks contain small amounts of vitrinite particles, which may have been reworked from older deposits. These measurements are therefore less accurate and less reliable than those of samples from the Westphalian coals (Van Bergen et al., in prep). The measurements can, however, still be qualitatively indicative for the maturity. The combination of several organic geochemical indicators shows that the Lower Jurassic source rocks in the middle part of the crosssection are within the oil window (Van Bergen et al., in prep). The samples for these measurements were, however, taken from structural highs. In between these highs, where the Lower Jurassic is buried to much larger depths, these source rocks are consequently likely to be much more mature. As a result, the Lower Jurassic source rocks may have reached the gas window at some locations, which is confirmed by the contribution of these source rocks to gas accumulations in Lower Cretaceous reservoirs (De Jager et al., 1996).

\section{Modelling methodology for hydrocarbon gener- ation and migration}

The tool used for the modelling of the hydrocarbon systems is TemisPack (by I.F.P.). The tool is based on the description of physical and chemical phenomena that control the formation of commercial accumulations in the moving framework of a sedimentary basin: heat transfer, compaction, hydrocarbon generation, and two-phase fluid flow (Ungerer et al., 1990). These phenomena are captured in a collection of non-linear differential equations, which are solved using a finite-difference method. Oil and gas formation is simulated by kinetic models in which temperature, geological time, and organic type are the main parameters. The gridding of the cross-section is determined by input from the user.

Transient heat transfer is calculated from the timedependent thermal boundary conditions, radiogenicheat production, and the porosity-dependent conductivities and heat capacities of the sediments (Appendix A). The boundary conditions for the thermal modelling are zero heatflow across the lateral boundaries, a specified time-dependent paleotemperature at the sediment/water interface - which is adopted from Poelchau et al. (1997) - and a pre-determined heat- 
flow history at the lower boundary (the sediment/ basement interface), which is initially taken to be equal to the paleoheatflow determined by the tectonic forward modelling of the tectonic subsidence curves for the wells, Lir-45 and Was-23-S2 (Fig. 4; Appendix B). The calculated paleoheatflow is calibrated until a fit with vitrinite reflectances and present-day temperatures is achieved.

For the 2-D forward modelling of basin evolution, the modelled cross-section has to be explicitely defined for a number of time steps. The time steps are taken in such a way that they represent the boundaries of important depositional units or erosional events. The basin evolution in between those time steps is obtained through linear interpolation. Paleowaterdepths and thicknesses of eroded and deposited bodies are implicitely defined. In order to reduce the complexity and the calculation time of the forward modelling, the stratigraphy has been simplified in the model cross-section. The simplification is based on the hydrogeological characteristics of the sediments (Appendix A), on the source-rock distribution and on the tectonic evolution of the basin (see Fig. 3).

The sediment properties, such as conductivity, have been specified for end-member lithologies, like shale and sandstone. The adopted values for the input parameters are discussed in Appendix A. The material properties of the modelled successions are calculated from their composition in terms of the end members, which are based on the lithological descriptions in the Dutch nomenclature (Van Adrichem Boogaert \& Kouwe, 1993-1997). The 'averaging' equations are straight forward (i.e., arithmetric mean, geometric mean, etc.). Calibration of the modelling results is achieved by comparing predicted permeability, porosity, temperature and vitrinite reflectance to observed values.

No significant overpressures have been encountered in the WNB. The predicted present-day fluid pressures should therefore be hydrostatic.

\section{Faults}

The sealing potential of faults is, as a rule, determined by the shale content of the displaced lithologies, the fault offset, stresses acting on the fault zone and mineralizations (Sibson, 1994; Moretti, 1998; Van Balen \& Skar, 1999). Most of the published work on this topic is compatible with a scheme in which the hydraulic properties of faults evolve through time (Moretti, 1998; Van Balen \& Skar, 1999). Active faulting may cause a fault zone to increase its permeability temporarily. This permeability will quickly be lost, however, due to stress or fluid-pressure decrease after faulting, or due to mineralization of the fault zone (Moretti, 1998; Van Balen \& Skar, 1999).

The sealing potential of faults in the WNB has not been studied. Based on the fact that fault zones provide lateral seals to hydrocarbon accumulations in Triassic reservoirs (De Jager et al., 1996), most faults, however, are suspected to be sealing currently at the Triassic level. This is not surprising given the fact that these reservoirs are juxtaposed to clay-dominated Lower Jurassic successions. The variation of the hydraulic properties of these faults along dip and in time is, however, largely unknown. The hydraulic properties of the fault zones in the simulations presented below are therefore the same as those of the displaced sediments, with the exception of one scenario in which the faults are assumed to be relatively open for fluid flow during the inversion events; it is assumed in this scenario that the active faulting during inversion created temporary fracture pathways for fluids.

\section{Modelling results}

In order to show the details of the hydrocarbon systems of the WNB, the modelling has been subdivided into three parts: one for each source rock. The predicted temperatures, pressures and vitrinite reflectances are, however, independent from the adopted source rock. They are therefore presented first to show the validity of the burial, thermal and compaction parts of the model. Present-day temperatures for offshore wells of the WNB, based on bottom-hole temperatures (BHT), were given by Robertson Research International (1988). The temperatures for the well Was-23-S2 have been estimated by extrapolation from the offshore wells Q13-1 and Q13-2, and temperatures for the well Hag-2 are based on extrapolation from Q16-1 and Q16-2. Temperatures for the wells Nwk-2 and Gag-1 have been determined using non-published BHT data (NAM, internal reports).

The predicted present-day temperatures versus the observed temperatures for four different locations are presented in Figure 6. The results show that, in general, a good fit is obtained. In more detail, a mismatch exists between modelled and predicted temperatures for the deeper part of the Was-23-S2 well. We have, however, no insight in the error bars associated with these BHT-derived temperatures. The general obtained fit is therefore neither worse nor better than a model that would fit all the data points. Moreover, we have no founded explanation for the mismatch, apart from mistakes in the projection of temperatures of the offshore wells to the wells on the profile.

The adopted vitrinite reflectance data set is from 

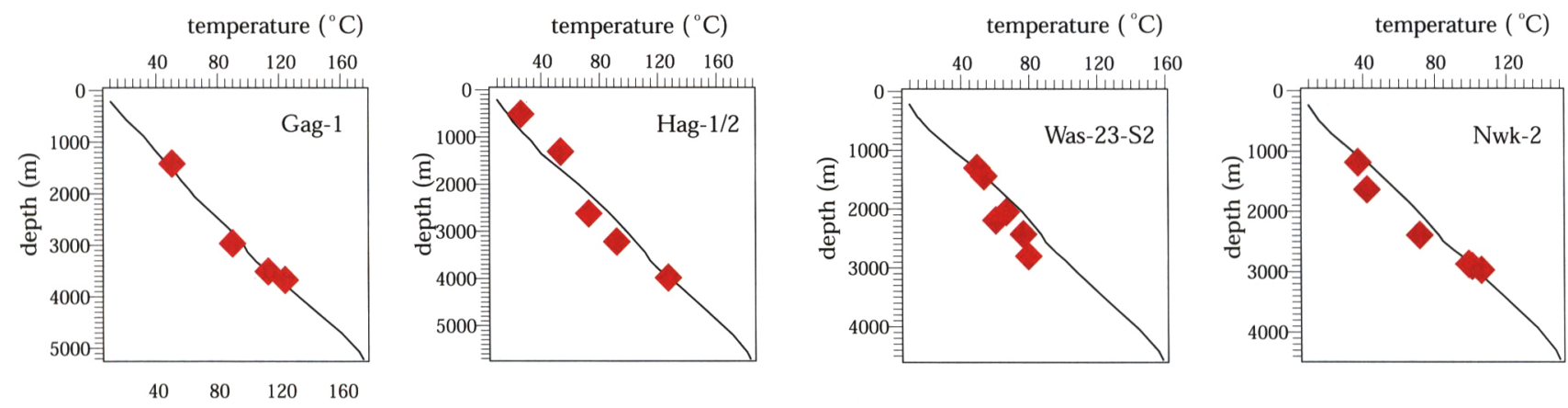

Fig. 6. Predicted temperatures (drawn line) versus observed temperatures (squares) with increasing depth for the wells Gag-1, Hag-1/2, Was23-S2 and Nwk-1.
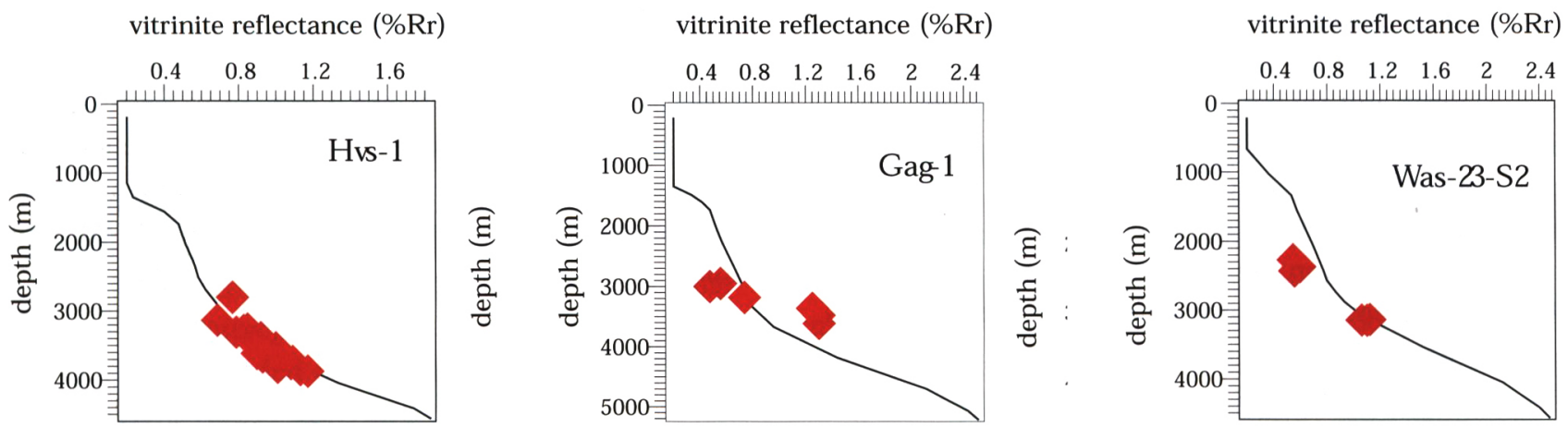

Fig. 7. Predicted vitrinite reflectances (drawn line) versus measured vitrinite reflectances (squares) with increasing depth for the wells Hvs-1. Gag-1 and Was-23-S2.

Van Bergen (1998). Uncertainty for the vitrinite reflectances (Fig. 7) is equal to the standard deviation of the measurements. The predicted vitrinite reflectances, based on the Type IV (I.F.P.) reference kerogen, fit all the available data. In Figure 8, the predicted fluid pressure for well Lir-45 is compared to pressure data from RFT measurement for the onshore part of the WNB (NAM, internal reports). This figure shows that the hydrostatic pressure gradient predicted in this well is in accordance with the available pressure data.

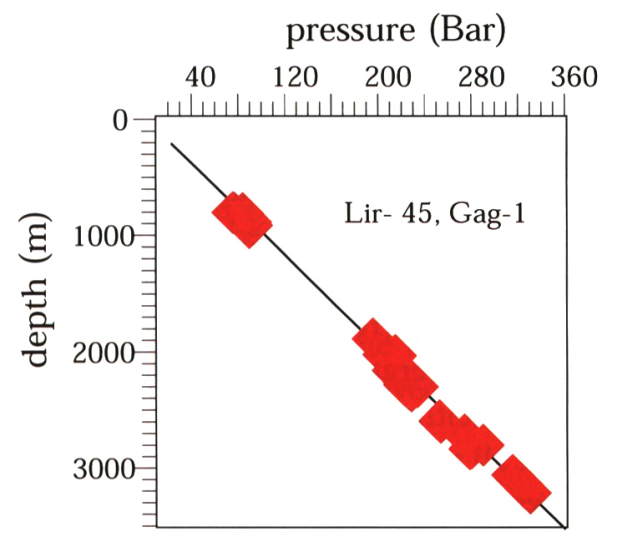

Fig. 8. Predicted observed fluid pressure for wells Lir- 45 and Gag-1 (drawn line) versus a collection of observed fluid pressures (squares) in the onshore part of the West Netherlands Basin.

\section{The Lower Jurassic oil system}

The source rocks adopted in this model are the Aalburg Formation, with a TOC of $3 \%$, and the Posidonia Shale Formation, with a TOC of $8 \%$. This hydrocarbon system has been forward modelled using a scenario in which faults have the same hydraulic characteristics as the displaced lithologies, and a simulation in which fault zones have time-dependent hydraulic properties. Because of the details of the hydrocarbon system and the lack of source rocks in the northern part of the cross-section, modelling results are shown for the southernmost $50 \mathrm{~km}$.

\section{Results of a scenario excluding the effect of faults}

The present-day saturation predicted by the modelling is shown in Figure 9. The results show that the source rocks have a hydrocarbon saturation of at most $60 \%$ in the deep parts of the southern half of the section. In the remainder of the section, source-rock hydrocarbon saturations are at a relatively low level (10$25 \%)$. The generation history of the Lower Jurassic source rock at the position of Hvs-1, Lir- 45 and Was23-S2 is shown in Figure 10a. The generation of hydrocarbons of these three locations starts during the Late Jurassic-Early Cretaceous rifting. This is the combined effect of increased heatflow due to litho- 


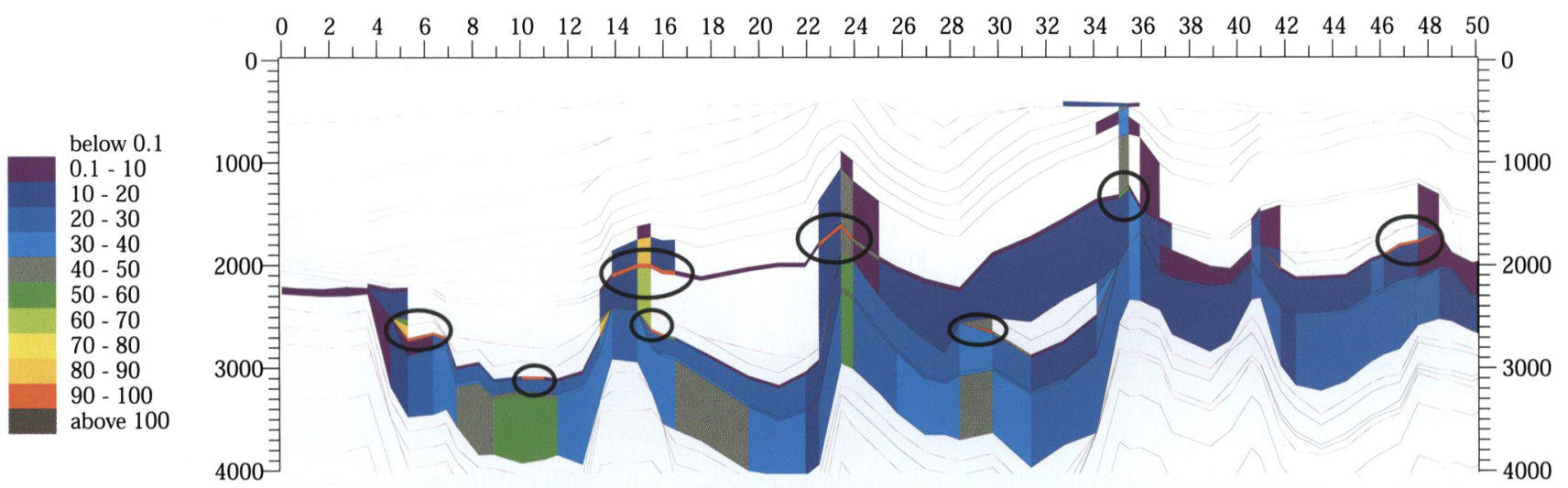

Fig. 9. Present-day hydrocarbon saturation for the Lower Jurassic oil system. Results obtained with a model that excludes the effects of faults on the fluid movements. Important hydrocarbon accumulations are encircled.

spheric extension and deeper burial caused by subsidence. The generation rate increased from south (Hvs-1) to north (Was-23-S2) along the section, which is directly related to the northward increase in the intensity of rifting and in the increase in thickness of Late Jurassic-Early Cretaceous deposits. Generation ceased at Was-23-S2 since the Late Cretaceous, because the burial depth stayed more or less the same since then: uplift and erosion during the inversion phases were more or less equal to the thickness of the Upper Tertiary.

A similar reason can explain the end of hydrocarbon generation at the position of Lir-45 in the Middle Tertiary: the netto burial depth has stayed more or less the same since then. At the position of Hvs-1, however, the source rock is at present at maximum burial depth so that hydrocarbons are currently still being generated at this position.

The predicted hydrocarbon saturation for reservoir intervals shows that known oil accumulations in the Lower Cretaceous reservoirs are reproduced by the model, i.e. the De Lier field at $15 \mathrm{~km}$ and the Wassenaar field at $36 \mathrm{~km}$ (Figs. 1, 2). An additional large accumulation is predicted at $23 \mathrm{~km}$ (Den Haag). Oil shows were found in Paleocene sediments in a well (De Mient, Mnt-1) drilled at this location (Boden- hausen \& Ott, 1981). The saturation history for the Lower Cretaceous sandstones of Lir- 45 and Was-23$\mathrm{S} 2$ is shown in Figure 10b. The results show that the anticlinal structures started to fill just after $80 \mathrm{Ma}$, after the Subhercynian inversion phase. The time difference of about $50 \mathrm{Ma}$ between the first generation and the first accumulation of oil is the effect of the long migration pathway through the Lower Jurassic claystones, via the dipping carrier sandstones of the Middle Werkendam Member and finally through the claystone-dominated Schieland Formation, into the reservoirs. The last part of the migration took place through the fractured core of the anticlinal structure. In addition, a minimum hydrocarbon saturation is required in the applied modelling software before migration can take place in each of the successions along the migration route.

Secondary hydrocarbon accumulations predicted by the model are situated in the sandstone of the Middle Werkendam Member at 5, 10, 16 and $47 \mathrm{~km}$ along the cross-section. The top seal for these faultdip accumulations are the shales of the Upper Werkendam Member. The side seal for the accumulations is provided by faults. To our knowledge, these potential accumulations have not been drilled, as the sandstone of the Middle Werkendam Member is consid-

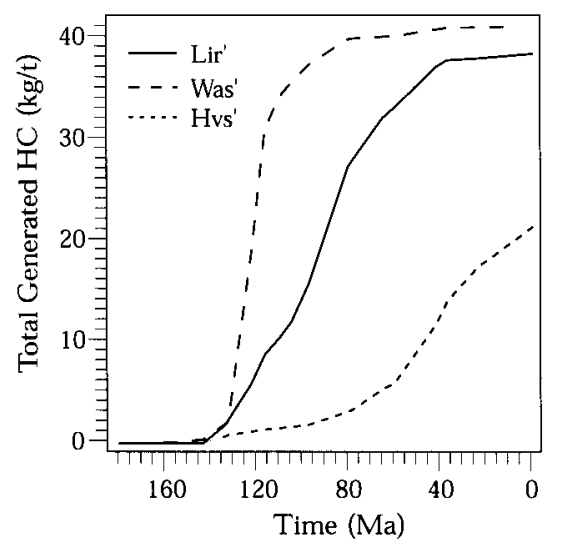

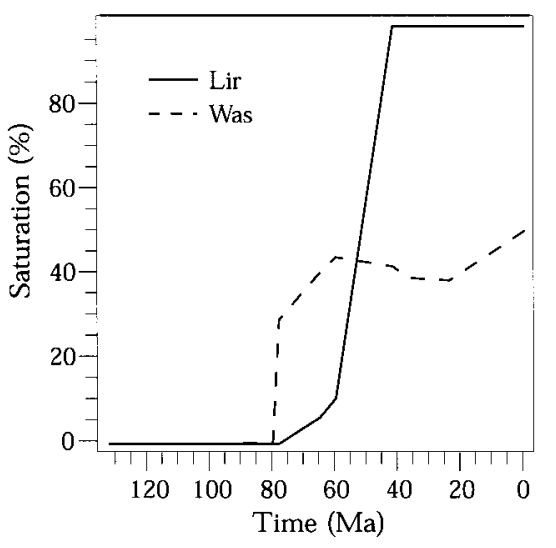

Fig. 10. Hydrocarbon-generation (left) and hydrocarbon-accumulation (right) histories for various positions along Figure 9 . 


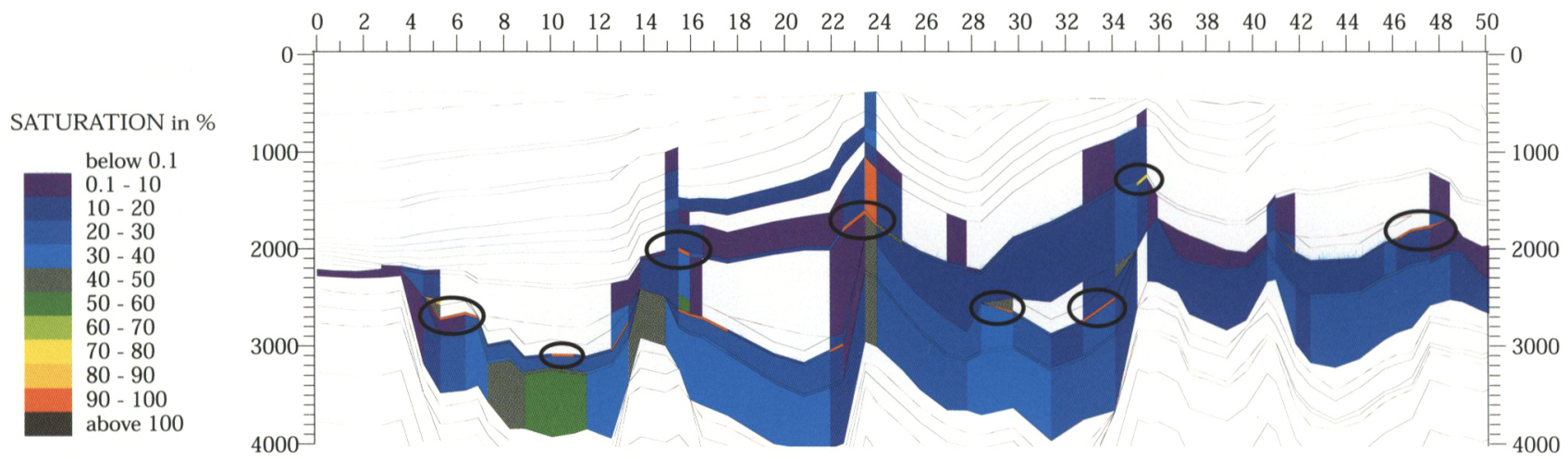

Fig. 11. Present-day hydrocarbon saturation for the Lower Jurassic oil system. Results obtained with a model that includes the effects of faults on the fluid movements. The permeability of faults was enhanced during the Late Cretaceous and Early Tertiary inversion events.

ered to be a secondary reservoir objective (see, a.o., Bodenhausen \& Ott, 1981; De Jager et al., 1996).

Results of a scenario including a fault permeability varying in time

In this model, the fault zones located at Den Haag $(25 \mathrm{~km}$ ) and at the De Lier and Wassenaar fields (Fig. 2) are included in the modelling. The fault zones were open for fluid flow during the Subhercynian and Pyrenean inversion phases (Fig. 3), due to fault movements. The 'opening' of faults has been modelled as a 1000 times increase in permeability during two restricted time intervals, each lasting $5 \mathrm{Ma}$. The effect of the opening of the fault zones on the predicted present-day saturation is minor (Fig. 11). The fault zones caused an improved drainage of the source rocks. The effect in the reservoirs was that the saturation became more concentrated. The leakage of hydrocarbons out of the reservoir towards the permeable overlying Lower Cretaceous units and towards the surface was enhanced. As explained before, this kind of modelling is, in our opinion, merely a guess due to lack of data in the WNB on the variation of hydraulic properties of faults along dip and in time and can therefore only be used for cosmetic effects.

\section{The Westphalian gas system}

The Westphalian Type III source rock adopted in this model has a TOC of $5 \%$. The present-day saturation predicted by the modelling is depicted in Figure 12 . The results show that the gas generated from the coals has been trapped in Main Buntsandstein Subgroup and Röt reservoirs and, in the northern part of the section, also in the Upper Permian sandstone. The model reproduces the accumulations in the De Lier (Gaag) field at $15 \mathrm{~km}$ and Wassenaar field at $36 \mathrm{~km}$. Additional large-sized fields are predicted at 0,24 , and $40 \mathrm{~km}$ along the model section. Smaller-sized fields are predicted at $6,11,50,53,61$ and $64 \mathrm{~km}$. The large predicted accumulation at $0 \mathrm{~km}$ is an effect of a boundary condition in the modelling. For the accumulation in the De Lier field, the model predicts a failure of the side seal, causing leakage of gas to the surface and to the Lower Cretaceous. The accumulation predicted at Den Haag $(24 \mathrm{~km})$ has not been drilled. All the wells in the neighbourhood of this accumulation were targeted at the shallower Lower Cretaceous sandstones. In the cross-section, the areal size of the predicted accumulation is twice as large as the areal size of accumulations that are, or have been, producing hydrocarbons (i.e., De Lier, Wassenaar). The

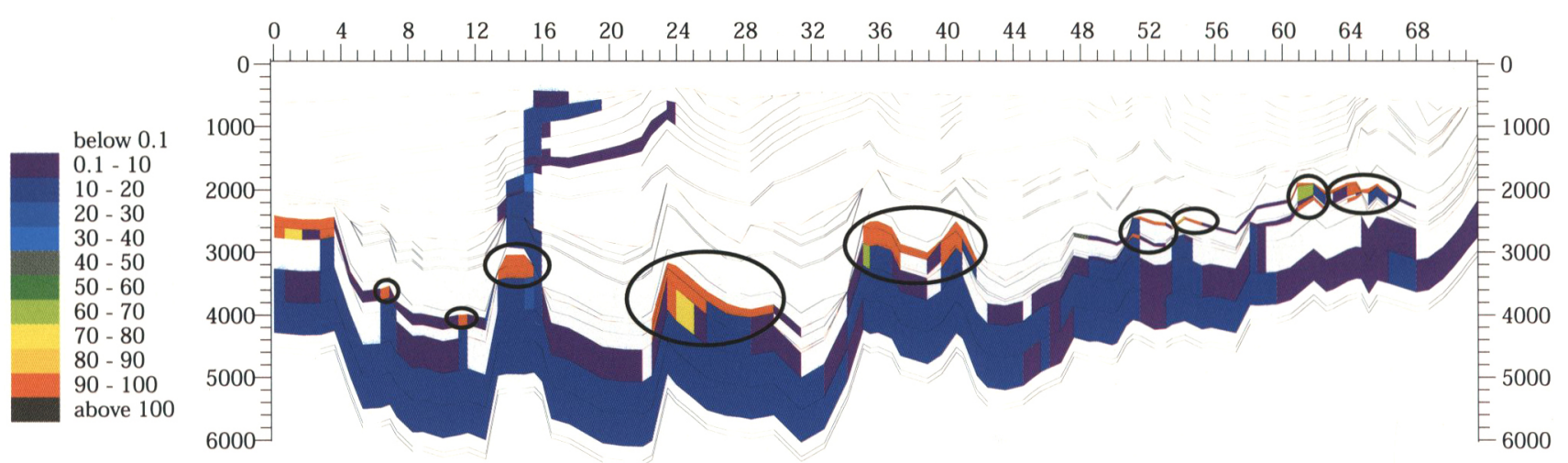

Fig. 12. Predicted present-day hydrocarbon saturation for the Westphalian gas system. 


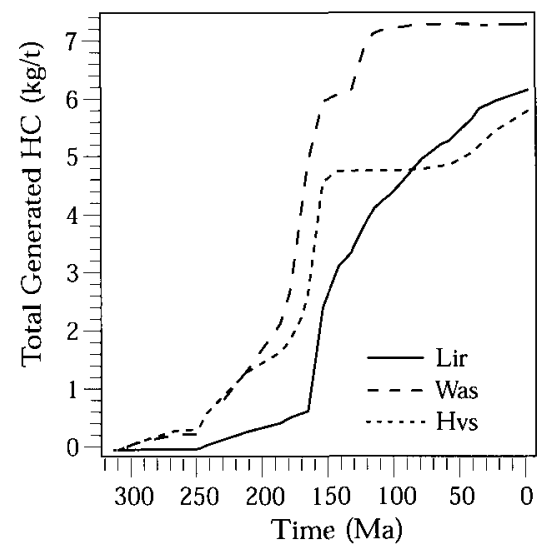

accumulation predicted at $40 \mathrm{~km}$ has not been drilled either, just like all the smaller-sized fields. Based on these 2-D modelling results, there could still be a considerable potential for gas accumulations in the WNB.

The timing of gas generation is depicted in Figure 13a. Generation set in at about $240 \mathrm{Ma}$, accelerated at $160 \mathrm{Ma}$, and leveled out towards the present. For the southern part of the section, generation continues until now; for the central and northern parts, the generation rate strongly declined at about $150 \mathrm{Ma}$. This was caused by differences in burial depths: in the central and northern parts of the section, the burial history resulted in most hydrocarbons being generated at about $150 \mathrm{Ma}$. The acceleration of generation at about 160 Ma was related to an increase in burial rate and an increase in heatflow, due to the Late JurassicEarly Cretaceous rifting.

The history of reservoir filling is shown in Figure 13b. The filling started at $150 \mathrm{Ma}$ and was completed at $118 \mathrm{Ma}$ for the De Lier and Wassenaar fields. These results are in accordance with the K/Ar dating discussed before. Filling of the predicted accumulation at the southern end of the section (Hvs-1) started relatively late compared to the rest of the section. This was caused by the difference in burial depths between these locations.

\section{The Namurian gas system}

In the model, the source rock is located at the base of the Namurian. The source rock applied in the model is of Type II and has a TOC of $8 \%$. Because the oils have been generated long ago, they probably have not survived, due to the high temperature and pressure conditions caused by burial. This is confirmed by the vitrinite reflectances predicted by the model (Fig. 7), which indicate that the Lower Namurian is overmature. Secondary cracking of oil to gas is therefore applied in the kinetic scheme. The model predicts trapping of the generated gas in the same structures as the Westphalian coal-derived gas (Fig. 14).

The generation history (Fig. 15a) shows that hydrocarbons were generated between 300 and $230 \mathrm{Ma}$, as a result of burial during the Late Carboniferous. The filling history of the Main Buntsandstein Subgroup reservoir (Fig. 15b) indicates, however, that it has taken until $150 \mathrm{Ma}$ before these hydrocarbons arrived in the reservoir; this is about simultaneously with the Westphalian coal-derived gas needed. In the model, the long migration time is the result of the low permeability of Upper Carboniferous strata.

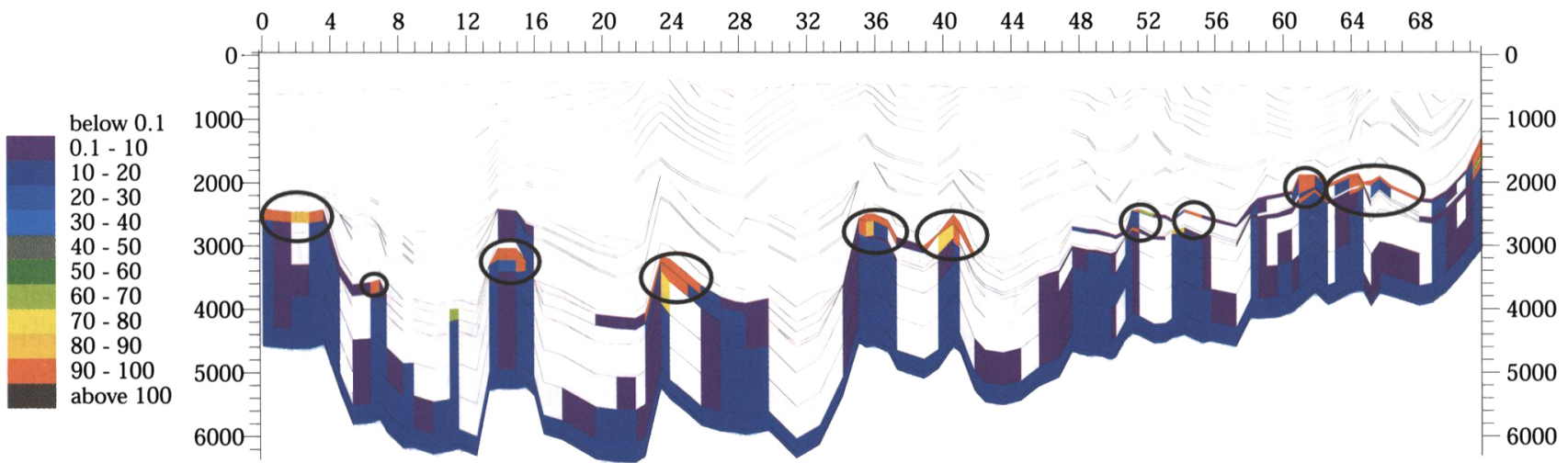

Fig. 14. Present-day hydrocarbon saturation for the Lower Namurian gas system. 


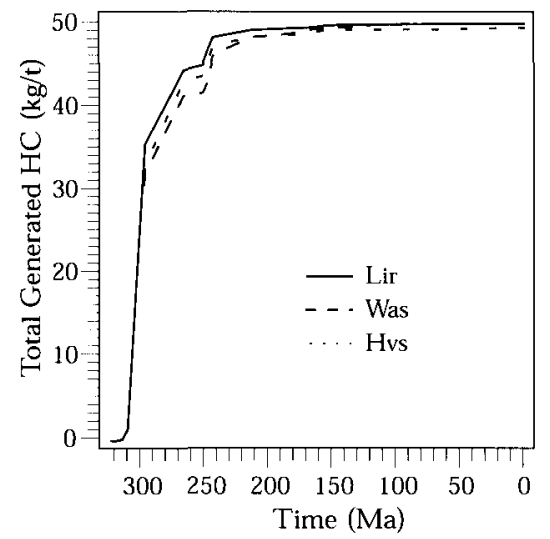

\section{Discussion and conclusions}

Forward modelling results of the Lower Jurassic oil system shows that the model reproduces known hydrocarbon accumulations in Lower Cretaceous reservoirs. An additional large-sized field is predicted at Den Haag $(23 \mathrm{~km})$. According to the Base-Aptian map by Racero-Baena \& Drake (1996), the 3-D structure of the trap indicates that the potential field is located a few kilometers offshore. The Lower Cretaceous reservoirs were filled just after the Subhercynian inversion event. As a consequence, the observed biodegredation of oils must have taken place during the Early Tertiary inversion phase. According to the model, the oils migrated through the Lower Jurassic claystones, via the dipping carrier sandstones of the Middle Werkendam Member, and finally through the claystone-dominated Schieland Group into the Lower Cretaceous reservoirs. The hydrogeologic properties of the Schieland Group were thus important for the migration of hydrocarbons. The sediments of the Schieland Group consist of sand-dominated fluvial deposits and floodplain and lacustrine fines (Van Adrichem-Boogaert \& Kouwe, 19931997). The connectivity of the sands determines the hydrogeologic properties of the succession. The connectivity is, however, unknown; in the model we assumed it to be negligible. Apart from the connectivity problem, isolated sand bodies may have trapped hydrocarbons within the Schieland Group. Further study into the sedimentology of the Schieland Group is required to elucidate these topics.

Results of the modelling of the Westphalian gas system show that larger-sized reserves potentially exist in the southern part of the cross-section. Particularly the predicted accumulation at Den Haag $(24 \mathrm{~km})$ has a large areal size. We have, however, no insight into the 3-D structure of this potential field. In the northern part, accumulations are predicted at both the Triassic and Upper Permian levels, making these sites prospective despite the limited thickness of the reser- voir horizons. According to the model, the reservoirs were filled during the Late Jurassic-Early Cretaceous rifting phase. The generation of hydrocarbons started $90 \mathrm{Ma}$ earlier.

Geochemical analyses of gases in Triassic and Permian reservoirs in the WNB and the western part of the southern North Sea Basin show that these gases are of mixed origin: a low-maturity terrestrial source and a more mature marine source (De Jager et al., 1996; Gerling et al., 1999). The first source is formed by the Westphalian coal deposits. The second source could be Lower Namurian marine hot shales. These shales have not been drilled in the WNB. In the Geverik-1 well, in the southeastern part of the Netherlands, these marine hot shales are $15-25 \mathrm{~m}$ thick and have a TOC of $8 \%$. They were probably deposited in a similar setting as the Lower Jurassic oil-prone shales (Van Adrichem-Boogaert \& Kouwe, 1993-1997). Based on the geological evolution of the Campine Basin (Langenaeker, 1998), these shales are assumed to be present below the WNB. Due to the high temperatures and pressures induced by the deep burial, the oils generated by these shales were converted to gas by secondary cracking. Modelling of the Lower Namurian gas system shows that mixing of Lower Namurian and Westphalian coal-derived gas in the Triassic reservoirs, as inferred from geochemical analyses, is likely. This modelling result is based on a scenario in which no potential traps are present in the Namurian and Westphalian series. This is, however, uncertain. Further research into the hydrogeologic characteristics of the Upper Carboniferous units is required to conclude whether traps can be present. Another direction of research should be aimed at the tectonic deformation of the Upper Carboniferous. Due to the inclination of permeable Upper Carboniferous strata beneath the Permian succession, excellent pathways may exist for the migration of hydrocarbons of the Namurian source rocks.

The time-dependent and along-dip variation of the hydraulic properties of faults in the WNB are un- 
known. The fact that fault-bounded hydrocarbon traps exist indicates, however, that parts of these faults are barriers to hydrocarbon flow starting from the time of filling of these traps. We assumed in the modelling that faults did not provide permeable pathways for hydrocarbons, with the exception of one scenario for the Lower Jurassic oil system. In this case, the faults were assumed to be open for fluid flow during the inversions. The modelling showed that, for this hydrocarbon system, the opening of faults did not affect the accumulation history very much, due to the timing of the migration with respect to the inversion movements. For the Westphalian and Lower Namurian hydrocarbon systems, however, the opening of faults would probably affect the predicted timing of the filling of traps and the amount of leakage to the surface, because the migration started in these hydrocarbon systems already during the Late Jurassic-Early Cretaceous rifting events. Future research on fault properties should be directed at the dependence of the faults' sealing capacity on their orientation, as faults with different orientations have probably different kinematic histories. In addition, a detailed study of the displaced lithologies and displacements would allow an assessment of the sealing capacity of faults.

\section{Acknowledgements}

We thank Petra David and Harry Veld for fruitful discussions on the organic geochemistry. Nora Witmans, Hans Doornenbal and Mark Geluk contributed significantly to this project. NAM is kindly acknowledged for providing data. Two reviewers provided valuable comments to the manuscript.

\section{References}

Andrews-Speed, C.P., Oxburgh, E.R. \& Cooper, B.A., 1984. Temperatures and depth-dependent heat flow in western North Sea. American Association of Petroleum Geologists Bulletin 68: 1764-1781.

Betz, D., Führer, F., Greiner, G. \& Plein, E., 1987. Evolution of the Lower Saxony basin. Tectonophysics 137: 127-170.

Bodenhausen, J.W.A.. \& Ott, W.F., 1981. Habitat of the Rijswijk oil province, onshore, The Netherlands. In: Illing, L.V. \& Hobson, G.D. (eds.): Petroleum geology of the continental shelf of NW Europe. Institute of Petroleum (London): 301-309.

Bodri, B. \& Jessop, A.M., 1989. Geothermal model of the continental margins of eastern Canada. Tectonophysics 164: 139-150.

Burrus, J. \& Audebert, F., 1990. Thermal and compaction processes in a young rifted basin containing evaporites: Gulf of Lions, France. American Association of Petroleum Geologists Bulletin 74: 1420-1440.

Burrus, J., Kuhfuss, A.,Doligez, B. \& Ungerer, P., 1992. Are numerical models useful in reconstructing the migration of hydrocarbons? A discussion based on the Northern Viking Graben. In: England, W.A. \& Fleet, A.J. (eds.): Petroleum migration. Geolog- ical Society Special Publication 59: 89-109

Burrus, J., Osadetz, K., Wolf, S., Doligez, B., Visser, K. \& Dearborn, D., 1996. A two-dimensional regional basin model of Williston basin hydrocarbon systems. American Association of Petroleum Geologists Bulletin 80: 265-291.

Cameron, N. \& Ziegler, T., 1997. Probing the lower limits of a fairway: further pre-Permian potential in the southern North Sea. In: Ziegler, K., Turner, P. \& Daines, S.R. (eds.): Petroleum geology of the southern North Sea: future potential. Geological Society Special Publication 123: 123-142.

Cornford, C., 1998. Source rocks of hydrocarbons of the North Sea. In: Glennie, K.W. (ed.): Petroleum geology of the North Sea, basic concepts and recent advances (4th ed.). Blackwell Science Ltd. (London): 376-462.

Danesh, A., 1998. PVT and phase behaviour of petroleum reservoir fluids. Developments in Petroleum Geoscience 47 (Elsevier, Amsterdam): $388 \mathrm{pp}$.

De Bremaecker, J.Cl., 1983. Temperature, subsidence, and hydrocarbon maturation in extensional basins: a finite element model. American Association of Petroleum Geologists Bulletin 67: 1410-1414.

De Jager, J., Doyle, M.A., Grantham, P.J. \& Mabillard, J.E., 1996. Hydrocarbon habitat of the West Netherlands Basin. In: Rondeel, H.E., Batjes, D.A.J. \& Nieuwenhuijs, W.H. (eds.): Geology of gas and oil under the Netherlands. Royal Geological and Mining Society of the Netherlands (KNGMG) / Kluwer Academic Publishers (Dordrecht): 191-209.

Dronkers, A.J. \& Mrozek, F.J., 1991. Inverted basins of the Netherlands. First Break 9: 409-425.

Dusar, M., Bless, M.J.M., Burger, K., Demaret, M., Hardy, M., Langenaeker, V., Lie Sun Fan, Paproth, E., Piérart, E., Somers, Y., Streel, M. \& Wouters, L., 1998. De steenkool verkenningsboring Hechtel-Hoef. Geological Survey Belgium Professional Paper 286: $129 \mathrm{pp}$.

Geluk, M., 1999a. Late Permian (Zechstein) rifting in the Netherlands: models and implications for petroleum geology. Petroleum Geoscience 5: 189-199.

Geluk, M.C., 1999b. Palaeogeographic and structural development of the Triassic in the Netherlands - new insights. In: Bachmann, G.H. \& I. Lerche (eds.): The epicontinental Triassic 1. Zentralblatt für Geologie und Paläontologie (in press).

Geluk, M.C., Plomp, A. \& Van Doorn, Th.H.M., 1996. Development of the Permo-Triassic succession in the basin fringe area. In: Rondeel, H.E., Batjes, D.A.J. \& Nieuwenhuijs, W.H. (eds.) Geology of gas and oil under the Netherlands. Royal Geological and Mining Society of the Netherlands (KNGMG) / Kluwer Academic Publishers (Dordrecht): 57-78.

Gerling, P., Geluk, M.C., Kockel, F., Lokhorst, A., Lott, H.K. \& Nicholson, R.A., 1999. NW European gas atlas - new implications for the Carboniferous gas plays in the western part of the Southern Permian Basin. In: Fleet, A.J. \& Boldy, S.A.R. (eds.): Petroleum geology of Northwest Europe - Proceedings of the Fifth Conference. Geological Society (London): 799-808.

Gras, R. \& Geluk, M.C., 1999. Late Cretaceous-Early Tertiary sedimentation and tectonic inversion in the southern Netherlands. Geologie en Mijnbouw 78: 1-19.

Harland, W.B., Armstrong, R.L., Cox, A.V., Craig, L.E., Smith, A.G. \& Smith, D.G., 1990. A geological time scale. Cambridge University Press (Cambridge): 263 pp.

Heybroek, P., 1974. Explanation to tectonic maps of the Netherlands. Geologie en Mijnbouw 53: 43-50.

Kooi, H., Cloetingh, S. \& Remmelts, G., 1989. Intraplate stresses and the stratigraphic evolution of the North Sea Central Graben. Geologie en Mijnbouw 68: 49-72.

Langenaeker, V., 1998. The Campine Basin, stratigraphy, structural 
geology, coalification and hydrocarbon potential for the Devonian to Jurassic. Ph.D. thesis Katholieke Universiteit Leuven (Leuven): $213 \mathrm{pp}$.

Lee, M., Aranson, J.L. \& Savin, S.M., 1985. K/Ar dating of time of gas emplacement in Rotliegendes sandstone, Netherlands. American Association of Petroleum Geologists Bulletin 69: 1381-1385.

Lippolt, H.J., Hess, J.C. \& Burger, K., 1984. Isotopische Alter von pyroklastischen Sanidien aus Kaolin-Kohlensteine aus Korrelationmarken für das mitteleuropäische Oberkarbon. Fortschritte Geologie Rheinland und Westfalen 32: 119-150.

McKenzie, D.P., 1978 Some remarks on the development of sedimentary basins. Earth and Planetary Science Letters 40:25-31.

Moretti, I., 1998. The role of faults in hydrocarbon migration. Petroleum Geoscience 4: 81-94.

Oakman, C.D. \& M.A. Partington, 1998. Cretaceous. In: Glennie, K.W. (ed.): Petroleum geology of the North Sea, basic concepts and recent advances (4th ed.). Blackwell Science Ltd. (London); 294-349.

Poelchau, H.S., Baker, D.R., Hantschel, Th., Horsfield, B. \& Wygrala, B., 1997. Basin simulation and the design of the conceptual basin model. In: Welte, D.H., Horsfield, B. \& Baker, D.R. (eds.): Petroleum and basin evolution: insights from petroleum geochemistry, geology and basin modelling. Springer Verlag (Berlin): 5-70.

Price, M., 1987. Fluid flow in the Chalk of England. In: Goff, J.C. \& Williams, B.P.J. (eds.): Fluid flow in sedimentary basins and aquifers. Geological Society (London) Special Publication 34: 141-156.

Racero-Baena, A. \& Drake, S.J., 1996. Structural style and reservoir development in the West Netherlands oil province. In: Rondeel, H.E., Batjes, D.A.J. \& Nieuwenhuijs, W.H. (eds.): Geology of gas and oil under the Netherlands. Royal Geological and Mining Society of the Netherlands (KNGMG) / Kluwer Academic Publishers (Dordrecht): 211-227.

Rijkers, R.H.B. \& Duin, E.J.Th., 1994. Crustal observations beneath the southern North Sea and their tectonic and geological implications. Tectonophysics 240: 215-224.

Robertson Research International 1988 Netherlands North Sea study: an integrated analytical and evaluation study incorporating petroleum geology, geophysics and reservoir engineering. Internal report Netherlands Institute of Applied Geoscience TNO - National Geological Survey (Utrecht).

Roelofsen, J.W. \& De Boer, W.D., 1991. Geology of the Lower Cretaceous $Q / 1$ oil-fields, Broad Fourteens basin, The Netherlands. In: Spencer, A.M. (ed.): Generation, accumulation, and production of Europe's hydrocarbons. Special Publication, European Association of Petroleum Geoscientists 1 Oxford University Press (Oxford): 203-216.

Royden, L. \& Keen, C.E., 1980. Rifting processes and thermal evolution of the continental margin of eastern Canada determined from subsidence curves. Earth and Planetary Science Letters 51: 343-361.

Sclater, J.G. \& Christie, P.A.F., 1980. Continental stretching: an explanation for the post Mid Cretaceous subsidence of the central North Sea Basin. Journal of Geophysical Research 85: 3711 3739.

Sibson, R.H., 1994. Crustal stress, faulting and fluid flow. In: Parnell, $\mathbf{J}$. (ed.): Geofluids: origin, migration and evolution of fluids in sedimentary basins. Geological Society Special Publication 158: 137-156.
Spain, D.R. \& Conrad, C.P., 1997. Quantitative analysis of top-seal capacity: offshore Netherlands, southern North Sea. Geologie en Mijnbouw 76: 217-226.

Steckler, M.S. \& Watts, A.B., 1978. Subsidence of the Atlantic type continental margin off New York. Earth and Planetary Science Letters 41:1-13.

Ungerer, P., Burrus, J., Doligez, B., Chénet, P.Y. \& Bessis, F., 1990. Basin evaluation by integrated two-dimensional modelling of heat transfer, fluid flow, hydrocarbon generation, and migration. American Association of Petroleum Geologists Bulletin 74: 309335.

Van Adrichem Boogaert, H.A. \& Kouwe, W.F.P., 1993-1997. Stratigraphic nomenclature of the Netherlands, revision and update by RGD and NOGEPA. Mededelingen Rijks Geologische Dienst (Haarlem) 50.

Van Balen, R.T. \& Y.Y. Podiadchikov 1998 The effect of inplane force variations on a faulted elastic thin-plate: Implications for rifted sedimentary basins - Geoph. Res. Lett. 25: 3903-3906.

Van Balen, R.T. \& Skar, T., 1999. The influence of faults and intraplate stresses on the overpressure evolution of the Halten Terrace, mid-Norwegian margin. Tectonophysics (in press).

Van Balen, R.T., Podladchikov, Y.Y. \& Cloetingh, S.A.P.L., 1998. A new multi-layered model for intraplate stress-induced differential subsidence of faulted lithosphere, applied to rifted basins. Tectonics 17: 938-954.

Van Bergen, F, 1998. Basin modelling and hydrocarbon generation in the WNB-an organic petrological and organic geochemical approach. Internal report Netherlands Institute of Applied Geoscience TNO - National Geological Survey (Utrecht) 98-148B: $120 \mathrm{pp}$.

Van Wees, J.D. \& Cloetingh, S.A.P.L., 1996. 3D Flexure and intraplate compression in the North Sea Basin. Tectonophysics 266: 341-359.

Van Wees, J.D. \& Stephenson, R.A., 1995. Quantitative modelling of basin and rheological evolution of the Iberian Basin (Central Spain): implications for lithospheric dynamics of intraplate extension and inversion. Tectonophysics 252: 163-178.

Van Wees, J.D., Arche, A., Beijdorff, C.G., López-Gómez, J. \& Cloetingh, S.A.P.L., 1998. Temporal and spatial variations in tectonic subsidence in the Iberian Basin (eastern Spain): inferences from automated forward modelling of high-resolution stratigraphy (Permian-Mesozoic). Tectonophysics 300: 285-310.

Van Wijhe, D.H., 1987. Structural evolution of inverted basins in the Dutch offshore. Tectonophysics 137: 171-219.

Vasseur, G. \& Demongodin, L., 1995. Convective and conductive heat transfer in sedimentary basins. Basin Research 7:67-79.

Verweij, H., 1999. Application of fluid flow systems analysis to reconstruct the post-Carboniferous hydrogeohistory of the onshore and offshore Netherlands. Marine Petroleum Geology (in press).

Voigt, E., 1963. Über Randtröge vor Schollenrändern und ihre Bedeuting im Gebiet der Mitteleuropäische Senke und angrenzender Gebiete. Zeitschrift der deutschen geologischen Gesellschaft 114: 378-418.

Winstanley, A.M., 1993. A review of the Triassic play in the Roer Valley Graben, SE onshore Netherlands. In: Parker, J.R. (ed.): Petroleum geology of Northwest Europe - Proceedings of the 4th Conference. Geological Society (London): 595-607.

Ziegler, P.A., 1990. Geological atlas of western and central Europe (2). Shell Internationale Petroleum Maatschappij / Geological Society Publishing House (Bath): 239 pp. 


\section{Appendix A: Modelling parameters}

The most important parameters refer to (1) thermal conductivity and (2) compaction and two-phase fluidflow.

\section{Thermal modelling}

Generalized thermal conductivities for heterogenious sediment successions in the western part of the southern North Sea Basin were taken from Andrews-Speed et al. (1994). For some successions, however, the Andrews-Speed et al. Data were too generalized. In these cases, applied conductivities have been based on values given by Burrus \& Audebert (1990), Ungerer et al. (1990) and Burrus et al. (1992). Additional mineralogy-dependent thermal conductivities were taken from Vasseur \& Demongodin (1995), who also provided the values for the conductivity anistropy of clay deposits that we have adopted in the modelling.

No data on radiogenic-heat production are available for the WNB. General values for this heat production inside the sediments are given by De Bremaecker (1983), Bodri \& Jessop (1989), Burrus \& Audebert (1990) and Van Wees \& Stephenson (1995). An intermediate value of $1 \cdot 10^{-6} \mathrm{~W} / \mathrm{m}^{3}$ has been adopted in the modelling.

Compaction and two-phase flow parameters (porosity, permeability and capillary pressure)

In the modelling, porosity is an exponential function of effective pressure. Observed porosity/depth data are transformed into a porosity-effective pressure relationship by assuming hydrostatic fluid pressures. Permeability is related to porosity by means of the Kozeny-Carman formula. Permeability is a scale-dependent parameter; it increases as the scale of observation increases. Permeability values determined on rock samples are therefore considered to be minimum permeabilities for the large-scale fluid-flow modelling. Available data are focused on the hydraulic parameters of reservoir rocks. The parameters for the porosity/permeability and the porosity/effective-pressure relationships for lithologies for which no or insufficient data exist (salt, evaporites, claystones, etc.) are based on Burrus \& Audebert (1990) and Burrus et al. (1992).

The Lower Cretaceous sandstones are characterized by a low to moderate permeability ranging from 10 to $4000 \mathrm{mD}$, and average porosities of about 12$30 \%$ (Roelofsen \& De Boer, 1991; Racero-Baena \& Drake, 1996). Present-day permeabilities for the sandstones of the Main Buntsandstein Subgroup can exceed $100 \mathrm{mD}$ (Winstanley, 1993). Data for Late Permian sandstones are available for two wells (NAM, internal reports) and are therefore augmented by data compiled for the Netherlands on- and offshore by Verweij (1999). The parameter values for the permeability/ porosity relationship for chalk are based on measurements by Price (1987). Due to lack of data, the parameters for marl and claystones are based on the mentioned literature.

Capillary entry pressures for gas for Upper Triassic deposits of the offshore part of the WNB were taken from Spain \& Conrad (1997). These data have been augmented by the general values for capillary entry pressures for gas and oil that were presented by Burrus et al. (1992) and Burrus et al. (1996). The applied parameter values for relative-permeability curves are the default TemisPack values (Ungerer et al., 1990).

The in-situ density of gas in an offshore Triassic reservoir in the WNB is inferred to be $269 \mathrm{~kg} / \mathrm{m}^{3}$ (Spain \& Conrad, 1997). The in-situ density of oil is unknown. This value has been calculated using the surface densities of non-biodegraded oils in the WNB, which vary around $750 \mathrm{~kg} / \mathrm{m}^{3}$ (H. Veld, pers. comm.). The surface density is transformed to an insitu density of $600 \mathrm{~kg} / \mathrm{m}^{3}$ using the dependence of oil density on pressure and temperature (Danesh, 1998). The densities of hydrocarbons have been held constant in the modelling.

\section{Appendix B: Paleoheatflow}

The history of heatflow along the cross-section was determined by tectonic forward modelling of the tectonic subsidence curves of the wells Lir-45 and Was-23-S2 (Fig. 4). The tectonic forward model is based on a depth-dependent stretching mechanism (McKenzie, 1978; Royden \& Keen, 1980). In this model, the crustal and subcrustal parts of the lithosphere are thinned during rifting. The synrift subsidence is caused by the local isostatic response to the decreased lithospheric load and the postrift subsidence is caused by the lithospheric density increase due to thermal contraction. The results of tectonic subsidence forward modelling therefore incorporate a model for the temperature evolution of the basin. The applied numerical model, described by Van Wees et al. (1998), automatically fits observed tectonic-subsidence curves, allowing for multiple finite stretching and compression events. The adopted pre-rift crustal thickness of $32 \mathrm{~km}$ was calculated from the depth to the Moho discontinuitiy and the lithospheric extension and compression factors determined by Rijkers \& Duin (1994). These factors are based on the ratios of lengths of the pre-rift base-Jurassic, the post-rift 

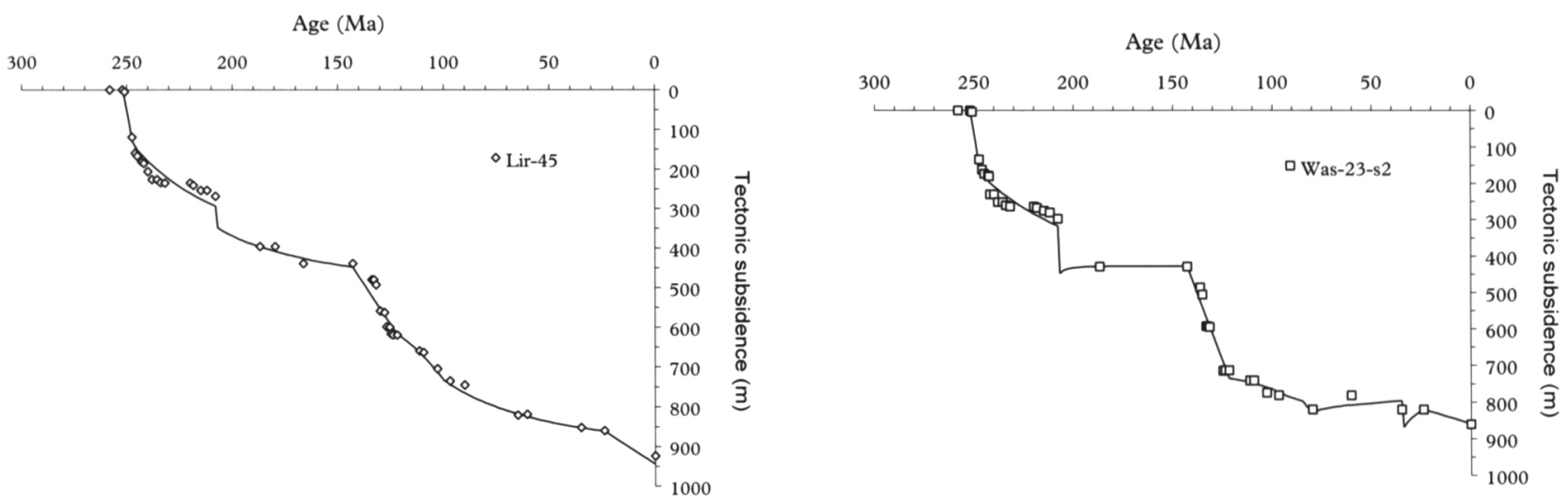

Fig. B1. Results of tectonic forward modelling of tectonic subsidence curves of two wells. The reconstructions are based on the local geological evolution.

Right: well Was-23-S2. For this the thicknesses of successions which have been eroded due to tectonic uplift have been reconstructed for the Late Cretaceous and Tertiary.

Left: well Lir-45.

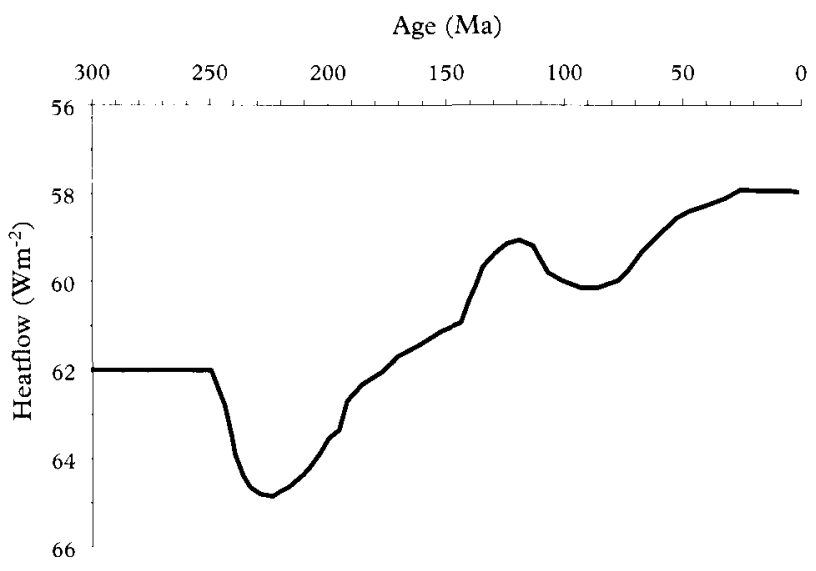

Fig. B2. Paleoheatflow values for well Lir-45 as determined by the forward modelling of tectonic subsidence.

base-Upper Cretaceous and the post-inversion topQuaternary reflectors. The values of other parameters used in the tectonic-subsidence calculations are based on Van Wees \& Stephenson (1995).

The Lir- 45 well has a nearly complete sedimentary record. In contrast, Upper Cretaceous and Lower Tertiary sediments are lacking in the Was-23-S2 well. The thicknesses of the eroded Upper Cretaceous and Lower Tertiary have therefore been estimated for this well from the local geological evolution and information from nearby wells. The reconstructed thicknesses have been used to adjust the tectonic-subsidence curve for this well in order to take into account the uplift and subsidence phases during the inversion periods (Fig. B1). The fitted subsidence models (Fig. B1) provide an estimate for the history of heatflow at the sediment/basement interface (Fig. B2). The rises in heatflow were caused by lithospheric thinning episodes. The effect of thinning was delayed, however, because of the time required to transport the heat through the lithosphere. In the strongly inverted areas, increases in heatflow were also caused by erosion during inversion episodes: the removal of sediment mass decreased the distance between the upper thermal boundary condition and the sediment/basement interface. 